
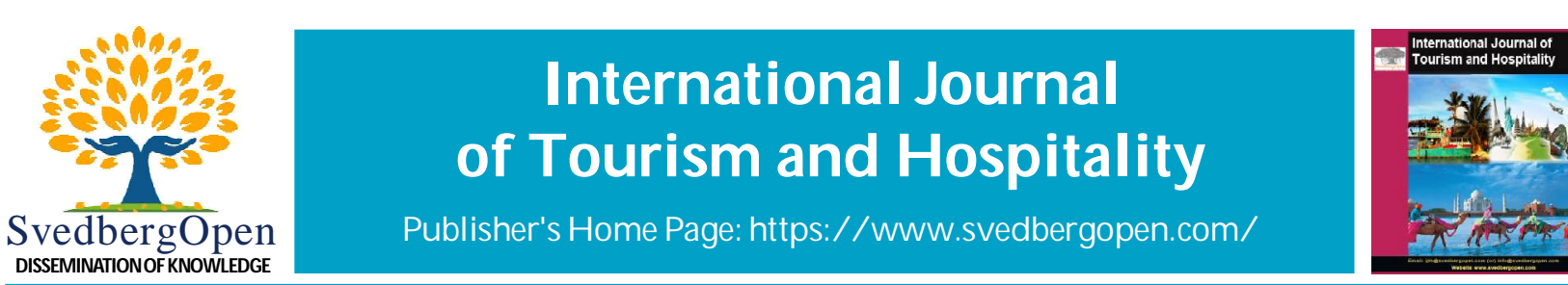

Research Paper

Open A ccess

\title{
Impacts of corona on tourism and small enterprises in Bangladesh
}

\author{
Md. Abdullah Al Naiem ${ }^{1 *}$ \\ 'BBA, Management Studies, MBA - Human Resource Management, Bangladesh University of Professionals. E-mail: mnaiem107@gmail.com
}

\section{Article Info}

Volume 1, Issue 3, July 2021

Received : 04 February 2021

Accepted : 19 June 2021

Published : 05 July 2021

doi: 10.51483/IJTH.1.3.2021.41-49

\begin{abstract}
This paper tries to find out the impacts of Corona on Tourism and Hospitality Industry in Bangladesh and presented some recovery plans for minimizing those negative impacts. This study is carried out based on the secondary data sources, various literature, newspapers, organizational and government publications, website materials and other sources are used to find out and complete the analysis. Corona has created an anxiety around the globe. Bangladesh has already started to face its horrible look. The economy of Bangladesh is just sunk and like other industries tourism industry is facing most awful situation ever before. Due to lockdown people cannot move from one place to another. As the number of Corona positive cases increasing day by day, government bound to take this hard decision (lockdown). All international flights have been cancelled and sowed for long days; accommodation business (hotels/motels/resort owners) already started to face a countless loss. Small hotels/ motels/restaurants/travel agencies already closed their businesses; thousands of people working in tourism industry have shared become jobless. Already government of Bangladesh offered different special packages for recovery and ensuring sustainability of different sector. Tourism industry also needs to offer different stimulus and discount packages for attracting domestic tourist which will help to recover the losses. This study also presents the real scenario of tourism industry during Corona pandemic which will help to know the update knowledge regarding the impact s of Corona on tourism and hospitality industry and to take proper recovery steps.
\end{abstract}

Keywords: Corona, Tourism, Tourism and hospitality industry, Economic and other effects, Recovering methods, Bangladesh.

(C) Md. Abdullah Al Naiem. This is an open access article under the CC BY license (https://creativecommons.org/licenses/by/4.0/), which permits unrestricted use, distribution, and reproduction in any medium, provided you give appropriate credit to the original author(s) and the source, provide a link to the Creative Commons license, and indicate if changes were made.

\section{Introduction}

Corona, an infectious disease caused by SARS-CoV-2, was first identified in December 2019 in Wuhan, Hubei, China (Mayo Clinic, 2020), but now the whole world is suffering from Corona outbreak. It creates an unstable and emerging situation around the world. Around two-million people in 185 countries around the globe have been identified as confirmed cases of Corona (Coronavirus) (Dong et al., 2020). Like others, Bangladesh is also suffering from Coronavirus pandemic. The country confirmed the first Corona case in its territory on March 2010 but now identified cases number crossed 145,483 in June 30, 2020 (Report of IEDCR, June 30, 2020). The number of infected cases as well as death cases is increasing day by day here and entire economy is facing a devastating situation. To reduce the spread of coronavirus, government took a lot of initiative like lockdown, general holiday, selection of restricted area, zone-wise lock down, etc.

\footnotetext{
* Corresponding author: Md. Abdullah Al Naiem, BBA, Management Studies, MBA - Human Resource Management, Bangladesh University of Professionals.E-mail: mnaiem107@gmail.com
} 
Due to lockdown, people cannot travel even in domestic area for long time. Travel activities were remained closed till second week of March 2020. Still now tourism spots are remained closed. Now, hotel, motel, restaurant, transportation facility are opened in a limited away. But people afraid to move and travel due to the increase number of Corona patients. Tourism and Hospitality industry stays at one of the major sector which going to look more shocking situation due to Corona outbreak. This study will discuss about the impacts of Corona on tourism and hospitality industry in Bangladesh and present some recovery plans for reshaping tourism industry to minimize present losses.

\section{Methodology}

This study is basically qualitative in nature and necessary data are collected from different secondary sources. Data are collected from different newspapers, articles, journals, UNWTO's (United Nations World Tourism Organizations) reports, World Health Organization's reports, tourism related various organizations' (PATA, TEAB, TOAB, etc.) reports and other relevant secondary data sources.

\section{Analysis and findings}

Tourism industry does not deal with only one industry or sector it also connected directly or indirectly with other industries - attraction (natural and man-made attractions), transportation (surface, air and water transport system and providers), accommodation (hotel, motel, resort, home stay and others), intermediaries (travel agencies and tour operators), amenities providers (telecommunication, restaurants, food and beverage providers, entertainment facility providers, etc.) and others.

\section{Major constraints to SME development in Bangladesh}

Small and Medium Enterprises (SMEs) are heterogeneous by their characteristics, mode of operation and types of SME products and processes. As such it is difficult to make sweeping generalization about constraints facing SME entrepreneurs. Some of the major constraints are discussed below:

\subsection{Inability to market SME product}

The present and future growth prospect of any product depends to a large extent upon marketing activity. This requires having a well-planned marketing strategy including advertisement campaign as well as resources for implementing that strategy. Unfortunately, SME entrepreneurs are at the bitter end in this respect as they cannot make adequate investments in marketing and also lack necessary marketing skills.

\subsection{Inability to maintain product quality}

A major constraint to the sustainability of SME growth in Bangladesh is the inability to maintain the quality of SME products. At present Bangladesh produces mostly common consumer goods which are labor-intensive and require relatively simple technology. But due to poor quality these products cannot stand competition from imported products. The challenge for Bangladesh today is not in competing with high-tech products of developed countries but to make its SME sector survive competition from its rivals.

\subsection{Lack of investment finance and working capital finance}

It goes without saying that access to finance particularly working capital finance and investment finance to enable them to expand their business is a prime constraint facing the SMEs. Banks in general do not consider SME financing as profitable activity. SMEs are also regarded as high risk borrowers because of their low capitalization, insufficient assets and high mortality rates, and consequently banks are not keen to offer them credit at comparable interest rates. SMEs in the export sector also face problems of access to working capital.

\subsection{Lack of skilled technicians and workers}

Lack of skilled manpower is a perennial problem in Bangladesh. This problem is particularly acute for small and medium scale export-oriented enterprises. Bangladesh has made large inroads in the world's apparel market through commendable performance of Readymade Garment (RMG) sector. However, the value addition of the products is low. Despite high demand, Bangladesh cannot make much entry into high value fashion wear exports due to dearth of trained workers. Supply capacity is thus constrained by non-availability of skilled workers.

\subsection{Poor management skills of entrepreneurs}

In the modern day economy, managerial skills for undertaking planning, marketing, and cash-flow management are vital for survival of an industry, small or large. SME entrepreneurs in Bangladesh are very much lacking in managerial skills and are not used to strategic planning. 


\subsection{Absence of supportive help desks}

In a competitive world, market information regarding demand and supply situation for a product at a particular period, changing consumer tastes, etc. are crucial elements for the success of an SME. In Bangladesh, although some financial institutions and few trade bodies like Dhaka Chamber of Commerce (DCCI) have introduced help desk and knowledge centers with internet facilities, such services are too few to provide service to the SME entrepreneurs on the whole. Lack of market information is a serious constraint to SME development.

\subsection{Non-Tariff Barriers (NTB) and changes in world trade regimes}

Liberalization of industrial and trade regimes in the wake of globalization are likely to have significant effects on Bangladesh's SMEs. Over the past decade there has been a significant change in the world trade regime with new regulations coming into effect.WTO agreements such as Application of Sanitary and Phytosanitary Measures (WTO SPS Agreement) to trade in agriculture products puts NTB restrictions on trade. WTO agreements not only cover the traditional goods sector, but also new sectors like services. Lack of knowledge about the current status of WTO Agreements hampers trade and business. Long-run economic prosperity will critically hinge upon turning the challenges of globalization into opportunities.

\subsection{Enabling environment for Trade and Business}

Although trade and business activities are carried out by the private sector independent of government control, existence of enabling environment like supportive regulatory framework, congenial tax regime, developed transport and communications infrastructure is vital for SME development. Bangladesh has made some progress in this direction but it still falls short of present day needs.

Other constraints of a general nature are inefficient infrastructure support especially power, widespread tariff anomalies, low productivity of labor, low level of technology, lack of research and development and low level of education of SME entrepreneurs in general.

\subsection{Barriers in access to finance for women entrepreneurs}

Discrimination still exists regarding access to finance by women entrepreneurs. Studies on the subject noted that women contribute around $26 \%$ in total deposit of the banking system but their access to credit is below $2 \%$ of the total outstanding loans. This is an unfortunate situation. Access to finance is one of the most critical constraints faced by women entrepreneurs. Although most of the banks have SME banking, few women apply for the bank loans as they need to submit a number of statements such as bank statement of the enterprise, reference of guarantor etc. for collateral free loans. Problems were more pronounced for women entrepreneurs in the informal sector. A recent study noted that about $79 \%$ of women entrepreneurs in this sector had no access to formal financial institutions and depended on own savings and family as source of capital to start a business.

Banking system is not adequately focused on women-owned enterprises. Banks usually consider women entrepreneurs in SME to be high-risk borrowers. The kind of collateral usually 1

\section{Solutions of the problems}

\subsection{Solutions for combating with Covid-19}

\subsubsection{Concessional loan, government support and digital transformation will help SMEs' survival}

"Prevention is better than cure"-is a quote familiar to most of us. To date, there is no cure for Covid-19 and the only way left for us is prevention. The lockdown is mandatory for our survival — with the current healthcare infrastructure it will be painstakingly difficult for us to fight and win against this virus at a mass scale level.

Keeping this into consideration, what should be the way forward for the government? We propose some concrete recommendations.

Concessional financing: From the current international practices as well from our study we observed that $70 \%$ of the respondents asked for soft loans/working capital loans to survive the crisis. Banks and financial institutions may sanction up to BDT 25 lakh to women entrepreneurs against the personal guarantee. Entrepreneurs' credit limit may be ranged from BDT 50,000 to BDT 50 lakh.

However, current stimulus packages that are applicable through banks depend on existing relationships with SMEs which many of the smaller players won't have. That means they might not be able to avail these concessional loans. 


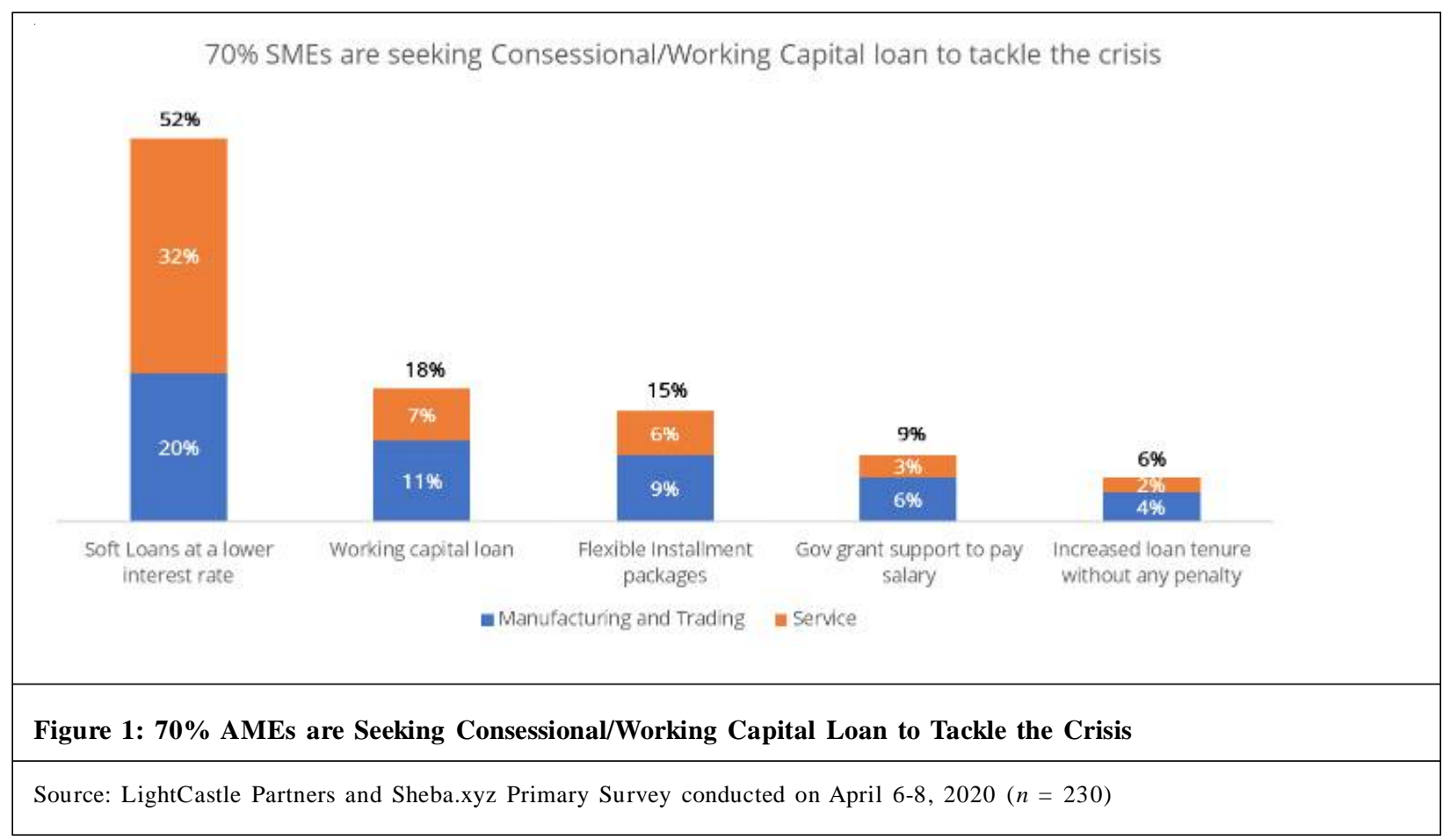

Moreover, the banking sector is going through a liquidity crisis with many of them having stretched NPLs (NonPerforming Loans); hence they might not be able to fully disburse the stimulus. Furthermore, they would be more willing to fund their existing clients rather than SMEs which require the most. Here again, we need a more ecosystem-centric approach, where MFIs whose current portfolio consists of $37 \%$ SME loan ${ }^{[5]}$ and has a wider reach, can come into play.

Tax reductions and grants: The government should be reducing the tax rate and offering grants to businesses in hardhit sectors in an effort to help reduce costs and boost the bottom line. Moreover, specifically for SMEs, VAT exemption on revenue and expenses for current and next fiscal year, exemption [or deferral] of withholding tax payments can be a timely initiative. By lower/exempting tax and providing grants, the impact of plunging aggregate demand as a result of the recession could be minimized.

Digital transformation: Within the scope of the government's financial assistance, the SMEs should try to digitize their business operations to the best of their ability. Since the lockdown is forcing people to stay inside homes, it is imperative that businesses switch to online channels. Linking up with mobile wallets, MFS (Mobile Financial Service), DFS (Digital Financial Service), and Digital Supply Chain Management will help towards achieving medium-term solutions to tackle the extent of the crisis.

- Digital financial services: Cashless transactions could transform the way SMEs conduct business. It widens the possibilities of reaching customers across the country. Mobile financial services like bKash, Rocket, UCash, Nagad opened new doors in transferring, transacting and storing money digitally instead of cash. Mobile Application \& Web-based financial services of banks provide faster and secured transactions with little or no human intervention. It solves the limitations of MFS as online-based banking services have greater transaction limits suitable for SMEs trading in large volumes. Nexus Pay (Dutch Bangla Bank), EBL Skybanking, BRAC Bank Mobile are a few of the leading mobile-based Digital Banking applications.

- Digital supply chain management: Supply chains having web-enabled capabilities render enterprises the ability to source and sell on digital platforms. This not only increases the potential market by folds but also ensures a seamless transaction and traceability from the factory to the consumers' doorstep.

- Digital credit: Traditionally, large banks that have had controlled capital investments in Bangladesh. Most financial institutions have been reluctant to lend beyond large corporates. One prevalent reason is assessing the creditworthiness of SMEs has been seen by banks as more difficult and expensive. Apart from providing a platform to SMEs for selling their products/services - Sheba.xyz and Shopup also provide digital credit to SMEs and smaller enterprises, which are underserved by traditional banks. They are also leveraging digital platforms to expedite credit assessments. 
In the short-term, e-commerce giants like Chaldal, Daraz, Pickaboo have been experiencing tremendous growth due to the lockdown; sometimes to an extent that leaves them unable to fulfill demand because of a supply shortage. Therefore, this brings great opportunities for rural SMEs; those who will be able to adapt will survive.

SMEs create livelihoods and if they fail we will go into deeper economic shock with more and more people coming below the poverty line. Hence, we all need to work together to support and uplift the sector. On the off chance that there is one thing that Covid-19 has shown unmistakably is that interest in digitization is not a luxury. Innovation is not only to survive this crisis but it is to create a sustainable business, which will be resilient and evolving in the 'new normal'.

\section{Long term solutions}

\subsection{Enhancing Access to SME Finance}

Access to institutional finance for SMEs is still greatly limited. Less than 30\% SMEs have access to institutional loans. Enhancing access to institutional finance by $50 \%$ of SME entrepreneurs may be a target within next five years.

\subsection{Development of SME infrastructure}

Infrastructure development is a prerequisite to efficient development and financing of SMEs. Currently, the most severe constraint that hinder the development of SMEs is the lack of infrastructure (e.g., roads, gas and electricity), limited access to market opportunities, technology, expertise and business information and communication. Providing appropriate infrastructure for SME growth should be given priority.

\subsection{Quality of SME products}

Poor quality of products is a big setback for expansion of SME business and SME sector as a whole. Measures for quality improvement and standardization of SME products have to be one of 17 the targets. The BSTI may be made more effective in monitoring quality of product both for domestic market and for exports.

\subsection{Training facilities for SME workers and entrepreneurship}

Bangladeshi workers are very good at learning production skills and copying them. However, training facilities for SME workers and development of entrepreneurial skills are not adequate in our country. Some training Institutes like the Training Institute of Bangladesh Small and Cottage Industries Corporation) (BSCIC) impart training but it is not utilized properly. Special programs are to be undertaken for the establishment of training institutes regarding entrepreneurship development.

\subsection{Organizing trade fairs, symposiums, workshops on SMEs on regular basis}

At present workshops and symposiums on SMEs are held by different organizations and think tanks, but these are held infrequently and not in any systematic manner. A plan of holding seminars, workshops, trade fairs, etc. on a regular basis should be formulated.

\subsection{Setting help desks in banks and business promotion bodies with internet facilities}

To extend the outreach of SME development particularly in respect of women entrepreneurs, a Help Desk with computer and internet facilities should be set up in bank branches dealing with SME finance as well as in all chambers of commerce and industry and other trade promotional bodies.

\subsection{Developing uniform definition of $S M E$}

There should be a uniform set of definitions for SMEs. This set of definitions should be the only definition used by all bodies and agencies connected with SMEs. Micro and cottage industries should also be defined accordingly.

So, Corona situation has more or less halted all of these mentioned sectors and directly or indirectly affect tourism industry. Tourism industry is one of the growing and potential drivers industries in the economy of Bangladesh. In 2018, its contribution in total GDP was $4.4 \%$ which is gradually increasing each year. The international tourism expenditure was worth $\$ 1208 \mathrm{mn}$ which belongs to comparatively moderate among the South Asian countries. But now this country has to face a different scenario due to Corona. 


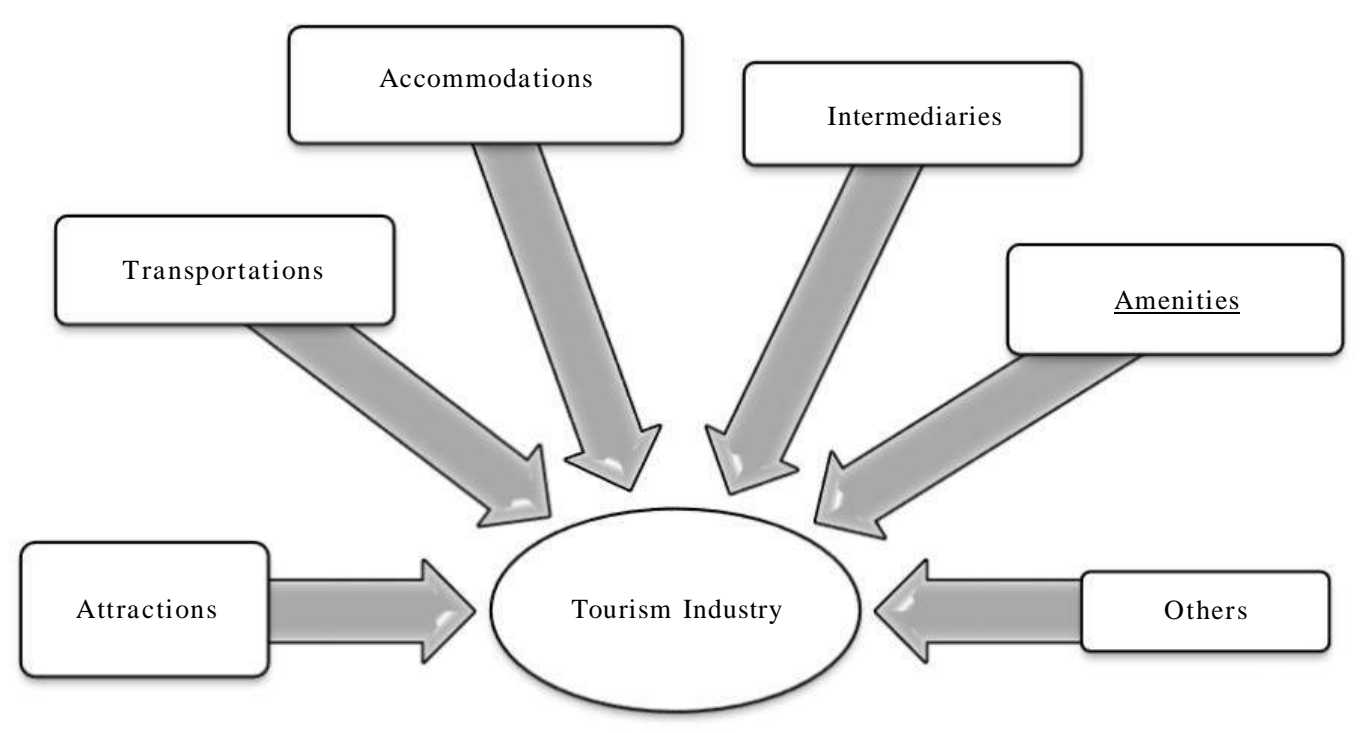

Figure 2: Components of tourism industry

Source: Developed by Author (2019)

In Bangladesh, November to June is the ideal time or peak season for tourism business. According to tourist experts, the months of February-March have long been the season most ideal for visiting the country's major beaches. This post winter time is best period for travelling country's one and only coral island-Saint Martin. Bangladesh tourism and hotel sector has fallen on real bad times. The impact of Corona has proved so massive that it might take years for the sector to return of its normal shape. It fell on the nation like bolt from the blue. Like all other sectors, people involved in the tourism business have started drawing a picture on estimated losses. With the popular spots lying deserted, hotels closed and the tour operator and other stakeholder s have to stop their work. So, they could find themselves one of the worst victims of coronavirus outbreak.

The World Tourism Organization's (UNWTO) mentioned in their site “Tourism Support Measure s" that Bangladesh tourism industry will face a loss of about TK 40 billion $(\$ 470 \mathrm{mn})$ this y ar. As all internationals fights postponed their operations and domestic travelers cannot move due to lockdown and facing current panic situation, tourism industry is facing more vulnerable situation right now.

Alongside, Tour Operator Association of Bangladesh (TOAB) forecasts that tourism sector of Bangladesh will suffer a loss of around TK 5,700 crore due to the outbreak of Corona. They forecast around 40 lakh people are employed in this sector (including tour operators, travel agents, hotels, motels, resorts, airlines, transportation, cruising, etc.) (The Business Standard, June 4, 2020). So directly or indirectly they are in great risk. TOAB president presented a proposal to get bank loan with a minimum interest rate and other government's support for survival of tourism industry (Travel Bangladesh, June 30, 2020).

Cox-bazar is known as the tourist capital of Bangladesh. The economy of cox bazar, Saint Martin Island is largely dependent on tourism. According to TOAB, only cox-bazar district is going to face a loss of BDT 20 billion revenue till Eid-Ul-Fitr. As aviation, tourism, hospitality, transportation and accommodation industries are interlinked to each other. All have to face trouble at their business. Aviation have to cancel their fight, hot 1, transportation are stopped due to lockdown. The shattering situation creates in hotel/motel/ resorts and other accommodation businesses. The occupancy situation of different $2 *$ to $5 *$ hotels around Bangladesh are shown in following figure:

Occupancy rate of all hotels are decreasing as well as wearing a deserted look due to Corona outbreak. According to the secretary of Bangladesh International Hotel Association, this time was the peak season and but due to Coronavirus now occupancy rate reduced by 30\%. Abu Hanif Bari, Company secretary and head of admin at Sena Hotel Development said "The Crushing impact of Coronavirus on the travel industry has had a devastating effect on hotels in Bangladesh". According to above Figure 3, The occupancy rate of hotel Amari Dhaka sank to just 10\%, The Six Season Hotel already lost TK 1.5 crore since the outbreak began. Occupancy rate of La Meridian Dhaka dropped from 90-95\% to about 60\%. 


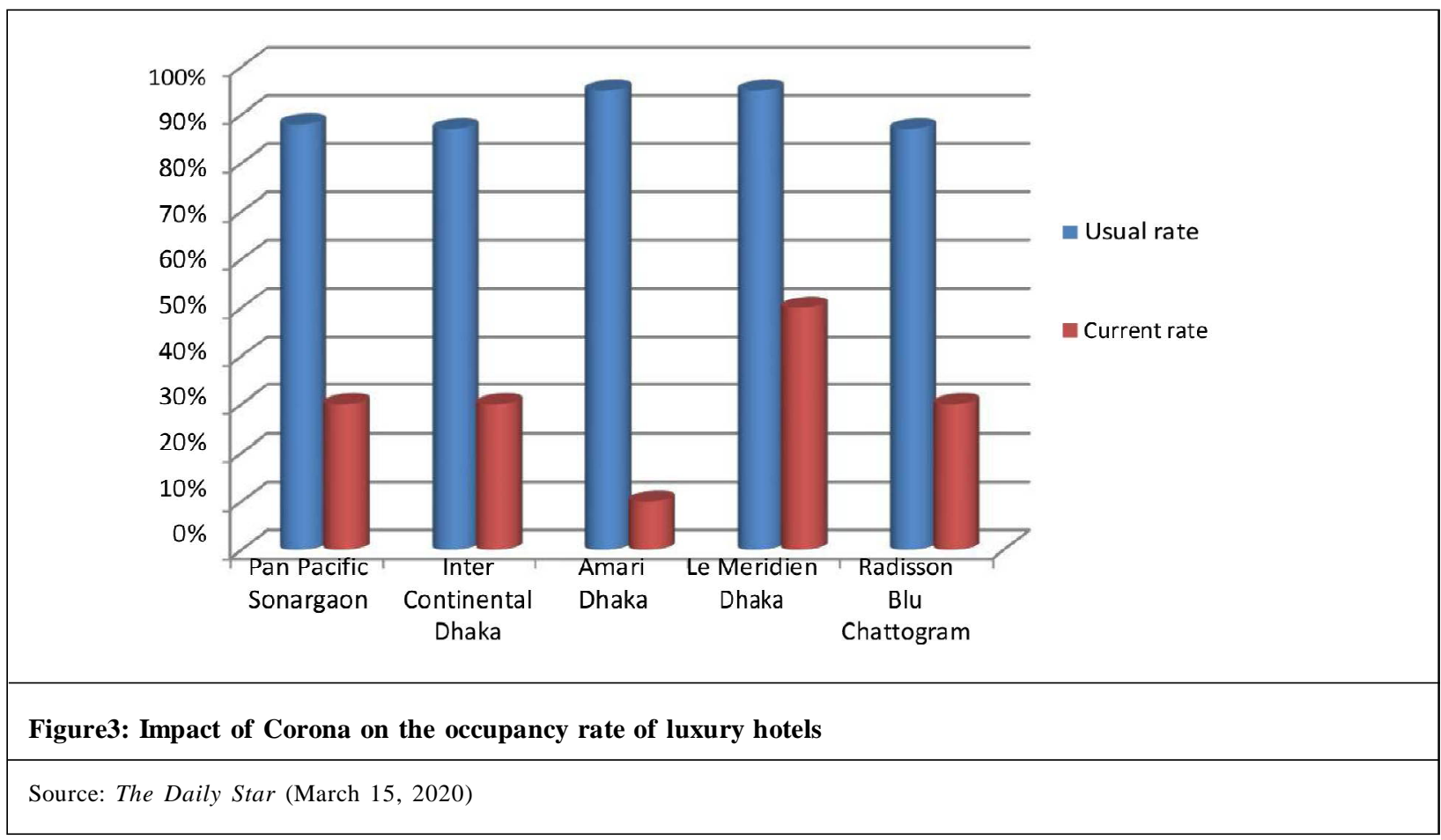

Hotel industry have started to close their some unique services as well as reducing the number of employees b cause this not possible to settle the payment of employee during this situation.

Not only hotel, aviation industries situation also catastrophic. The IATA forecasted that global air transportation revenue will be dropped by $11 \%$ in 2020 which means a loss of $\$ 163$ bn (IATA, 2020). They also forecast that around 25 million aviation-related jobs are at risk globally now. Due to this outbreak situation, flights have to cancel and stopped for long time which causes losses for airlines. The impacts of Corona on weekly flights number during the initial time of lockdown are shown below.

Airlines are obliged to suspend their International flights as per government direction. Government has cut air connectivity with other countries to curb the spread of Coronavirus in the country which also creates losses for airlines. According to the report of The Daily Star, local airlines were on course to losing TK 350 crore in revenue just in March month due to Corona pandemic situations around the globe. Figure 4 shows the flights number before and after lockdown which clearly shows the horrible situations of different airlines.

Moreover, different supportive organizations are trying to estimate and forecast the losses of travel and tourism sector and finding out probable recovery plan for reshaping country's tourism Industry. Pacific Travel Association (PATA) Bangladesh Chapter prepared a statistics presenting Corona's impact on tourism and present tourism industry's

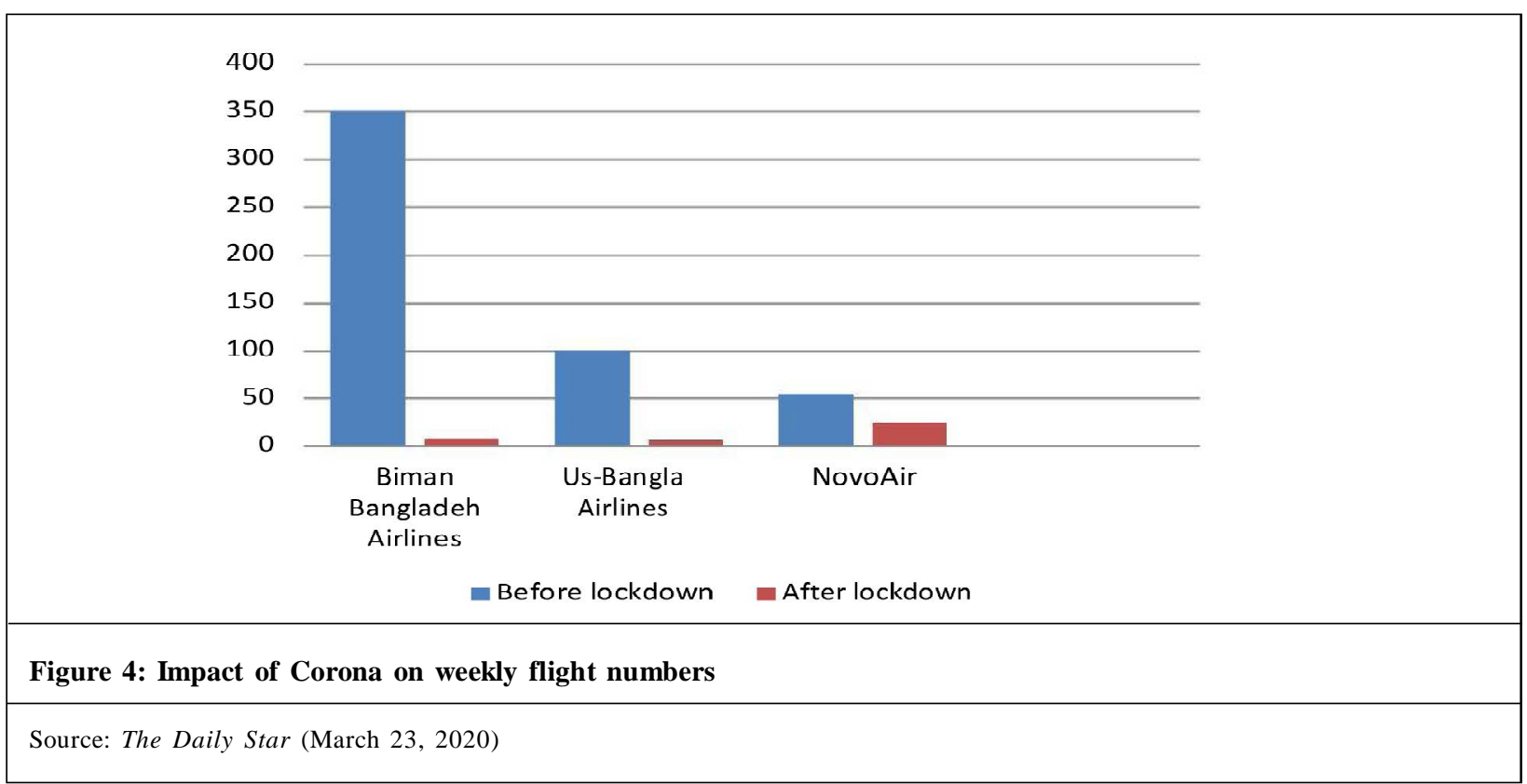


situation in Bangladesh. Tourism industry of Bangladesh largely depends on domestic tourism. About 10 million domestic tourists travel each year and the turnover is around 35 billion in a year. International travelers also cancelled their travel schedule due to Corona. Thousands of small hotel, resorts, motel, travel agencies and other travel related organization have to close their service due to this pandemic. Aviation industry is also going to face a great loss which estimated as loss of 6 billion taka and around 2,000 people involved with aviation industry will become jobless. The estimated losses of tourism and hospitality industry are presented in following graphs.

According to the mentioned Figures 5 and 6, hotel/resorts/INN $\left(2 *-5^{*}\right)$ are going to face a loss of 15 billion $(1,500$ crore) taka as a result of which 100,000 people will become jobless, travel agents going to face loss of 30 billion taka and to create 1,500 jobless people, tour operator (inbound) is going to face loss of 1 billion (100 crore) taka and create 1,000 jobless, tour operator (outbound) is going to face loss of 25 billion (3,000 crore) taka and create 15,000 jobless, Tour Operator (Domestic) is going to face loss of 1,000 crore taka and create 15,000 jobless, 4.5 billion taka loss will be faced only at UMRA (land package). Restaurants, coffee shop, bar and others will have to face a loss of 4.5 billion (500 crore) taka and to create height unemployed people (around 150,000 jobless). Transpiration directly or indirectly involved with tourism has to face a loss of 55 crore taka and to create 16,500 jobless people. So, the forecasted total loss till June 2020

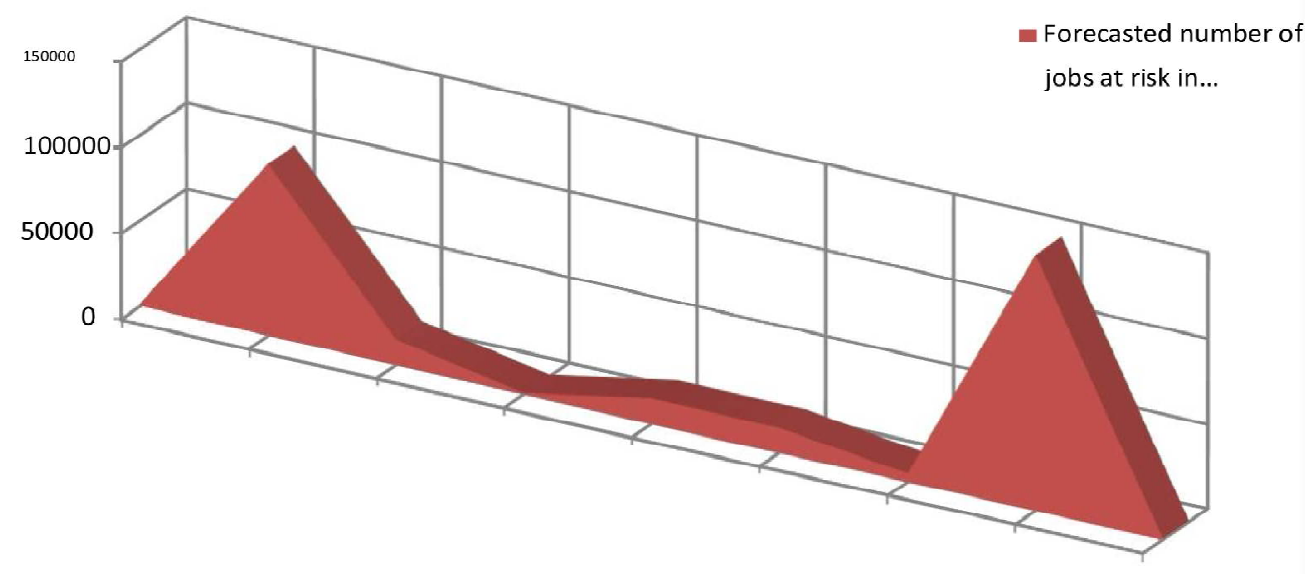

Figure 5: Forecasted number of jobless people in tourism and hospitality industry due to Corona pandemic

Source: PATA Bangladesh Chapter (2020)

\section{Forecasted losses in taka (crorers) in Tourism and Hospitality industry in Bngaldesh}

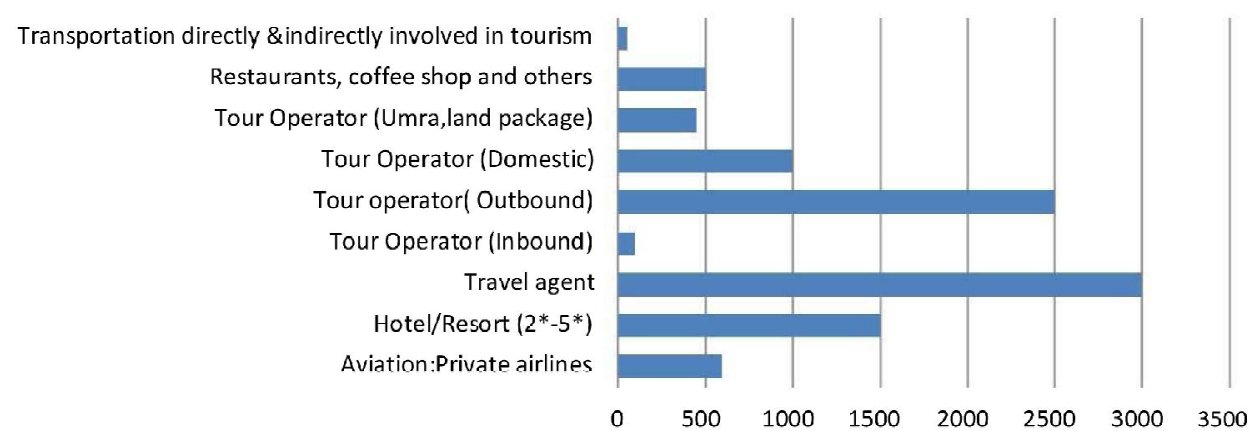

- Forecasted losses in taka (crorers) in Tourism and Hospitality industry in Bngaldesh

Figure 6: Forecasted losses in tourism and hospitality industry in Bangladesh due to Corona

Source: PATA Bangladesh Chapter (2020) 
is around 97.5 billion taka and more than 3 lakh people will become jobless which will create a devastating socioeconomic situation in Bangladesh.

So, it can be said that the entire tourism and hospitality industry around the globe is going to face a bog disaster and this will continue till the Corona situation become normal. Necessary steps and plans need to develop for recovering this estimated loss.

\section{Recommendations and conclusion}

As tourism industry works with the amalgamation of too many other industries, it's not possible to any single industry to recover the entire loss of tourism and hospitality industry. Both public and private relevant organizations need to come forward to take proper recovery plans. The Government of Bangladesh already announce its annual budget for aviation and tourism industry, now proper utilization of this budget is essential for recovery tasks. The Government of Bangladesh also announced a stimulus package to support the tourism sector where banks will provide loans at $9 \%$ interest and government will bear $4.5 \%$ interest and other $4.5 \% \mathrm{n} \mathrm{d}$ to be bearded by the business (UNWTO, April 9 , 2020). Now Bangladesh should focus on domestic tourism, special discount packages need to be developed to attract tourists. The promotion of village tourism, agro-tourism, and community-based tourism needs to be practiced which help to enhance visitors will interest of travel as well as improving the economic conditions of country. Moreover, policymakers must have to ensure and monitor the proper utilization of resources as well as proper execution of their recovery plans which will bear more fruitful result for tourism industry in Bangladesh.

\section{References}

Dong, E., Du, H. and Gardner, L. (2020). An interactive web-based dashboard to track Corona in real time, Lancet Infect Dis. 0.1016/S1473-3099(20)30120-1

PATA Bangladesh Chapter. (2020). COVID-19: Impact on the tourism and hospitality industry in Bangladesh". Available at https://www.pata.org/pata-bangladesh-chapter-covid-19-impact-on-the-tourism-industry-in-bangladesh/

The Finance Today published a report on "COVID-19 to cost BD's Tourism sector TK 40Bn: UNWTO. Available at https://www.thefinancetoday.net/article/tour sm/10890/Covid-19-to-cost-BDs-tourism-sector-Tk40bn-UNWTO.

IATA (2020). Updates covid-19 financial impacts-relief measured. Available at https://www.iata.org/en/pressroom/pr/ 2020-03-05-01/

Reported by Mahmudul Hasan, Local Airlines battling an existential crisis. The Daily Star. 23 ${ }^{\text {rd }}$ March 23, 2020.

Reported by Mahmudul Hasan, Coronavirous fears: Hotels become ghost downs. The Daily Star. March 15, 2020.

Tourism sector to lose TK 5700cr because of covid-19: TOAB. The Business Standard, June 4, 2020.

Bangladesh rural economy reels from shutdown. The Business Standard, June 13, 2020.

Written by Md. Ziaul Haque Howlader, Drawing up tourism recovery plan. Financial Express, June 13, 2020.

Mayo Clinic (2020). Coronavirus disease 2019(COVID-19) - symptoms and causes, Retrieved on April 14, 2020.

Report of IEDCR, June 30, 2020. Available at https://en.wikipedia.org/wiki/COVID-19_pandemic_in_Bangladesh\#30 June

Hafsa Shelamony (2020). Impacts of covid-19 pandemic on tourism \& hospitality industry in bangladesh. Available at : https://papers.ssrn.com/sol3/papers.cfm?abstract_id=3659196

https://www.lightcastlebd.com/insights/2020/04/covid-19-impact-on-bangladeshs-sme-landscape

Zaman, A.K.M. Helal uz and Islam, Md. Jahirul. (2011). SMEs Development in Bangladesh: Problems and Prospects.

Cite this article as: Md. Abdullah Al Naiem (2021). Impacts of corona on tourism and small enterprises in Bangladesh. International Journal of Tourism and Hospitality. 1(3), 41-49. doi: 10.51483/IJTH.1.3.2021.41-49. 